\title{
ZAKAT UNTUK PEMBANGUNAN MASJID
}

\author{
Zainuddin \\ Fakultas Syariah IAIN Batusangkar \\ J1. Jenderal Sudirman No. 137, Lima Kaum Batusangkar \\ e-mail: zainuddin@iainbatusangkar.ac.id
}

\begin{abstract}
This article presents an overview of Islamic Law on the properties of zakat used for the construction of mosques. This study uses literature research, because the study of Islamic law will seek answers through literature, both in the form of legal propositions and opinions of the scholars. From the results of this study found the answer that there are two opinions of scholars about the law of building a mosque with rakat property. The first opinion allows and the second opinion does not allow. While the author more tends to the opinion that does not allow, because zakat is the right of people (ashnaf) while the construction of the mosque can be obtained from wakaf ummah.
\end{abstract}

Kata kunci: zakat, pembangunan, masjid

\section{PENDAHULUAN}

Secara etimologi kata zakat berarti berkah, suci, tumbuh dan berkembang. Sedangkan secara terminologi adalah sejumlah harta tertentu yang dikeluarkan dan diserahkan kepada orang yang berhak menerimanya.

Selanjutnya kata masjid dalam bahasa Arab secara etimologi berarti tempat sujud, dan secara terminologi adalah suatu bangunan tempat ibadah yang digunakan oleh umat Islam terutama sebagai tempat dilangsungkannya shalat berjamaah. (Dahlan [et al.] 4:1119) Dalam pengertian ini tidak dibedakan antara surau, langgar dan mushalla dengan masjid. Kesemuanya bangunan yang digunakan untuk tempat shalat dan ibadah lainnya. Akan tetapi dalam pengertian sehari-hari di Indonesia antara masjid dengan surau, langgar dan mushalla dibedakan. Masjid di samping untuk shalat dan ibadah lain secara khusus digunakan untuk shalat Jum'at, sedangkan surau, langgar dan mushalla tidak demikian.

"Pembangunan" berasal dari kata dasar"bangun" mendapat awalan "pe" dan akhiran "an" yang artinya adalah perbuatan membangun (https://kbbi.kemdikbud.go.id/). Jadi "pembangunan masjid" maksudnya adalah membuat atau mendirikan masjid.

Di dalam hukum Islam telah ditentukan orang-orang yang berhak menerima zakat yang disebut dengan ashnaf (macam) yang delapan atau delapan macam orang yang berhak menerima zakat. Ayat-ayat Alquran atau hadis-hadis Nabi Muhammad Saw tidak menyebutkan bahwa masjid termasuk ke dalam ashnaf tersebut. Sementara itu ditemukan orang yang menyalurkan zakatnya untuk pembangunan masjid. Dengan kata lain pengurus masjid ada yang menerima zakat untuk pembangunan. 
Dari kenyataan ini muncul permasalahan bagaimana kedudukan hukumnya harta zakat digunakan untuk pembangunan masjid?, apakah boleh atau tidak.

\section{METODE PENELITIAN}

Tulisan ini menggunakan metode kajian kepustakaan (library research) yang bersifat kualitatif. Pembahasan yang dikemukakan didasari bahan-bahan yang diteliti melalui dalil-dalil Alquran dan Sunnah, kitab-kitab figh dan tafsir. Dari kitab-kitab tersebut dikutip berbagai pendapat dan argumentasi para ulama beserta dalil-dalil yang mereka kemukakan, kemudian ditarik suatu kesimpulan.

\section{PEMBAHASAN}

\section{Tinjauan Pustaka}

\section{Sejarah Pembangunan Masjid}

Pembangunan masjid sudah jauh sebelum Nabi Muhammad diutus. Masjid yang tertua adalah Masjidil Haram, di Mekah, yang dibangun oleh Nabi Ibrahim beserta putranya, Ismail. Masjidil Haram lebih dahulu 40 tahun dibangun dari Masjidil Aqsha di Yarussalem. Pada tahun ke-8 dari kebangkitan Nabi Muhammad Saw, Masjidil Haram dijadikan sebagai tempat ibadah bagi Umat Islam. (Dahlan [et al.]: 1139) Hingga sekarang masjid tersebut tetap menjadi tempat ibadah umat Islam sedunia, terutama di musim haji.

Masjid merupakan basis pembinaan umat Islam. Ketika Nabi Muhammad Saw dalam perjalanan hijrah ke Medinah beliau singgah di desa Quba dan di sini Nabi pertama kali mendirikan masjid yang kemudian dikenal dengan masjid Quba. (Dahlan [et al.]: 1134). Begitu juga selanjutnya ketika Nabi sudah berada di Madinah, beliau membangun sebuah masjid yang disebut dengan Masjid Nabawi. Dari masjid inilah Nabi memulai berbagai aktifitas untuk memimpin dan menggerakkan umat. Setelah umat Islam bersebar ke berbagai wilayah dan penjuru dunia hingga kini bermunculan masjidmasjid dengan jumlah yang banyak sekali yang sulit untuk mendapatkan data yang pasti.

Pembangunan masjid pada mulanya dilakukan dengan sangat sederhana. Masjidil Haram sebelumnya belum didinding. Pada masa Umar bin Khattab baru didinding dengan ketinggian tidak sampai setinggi badan. Masjid Quba hanya dibuat dengan batu bata merah dengan atap dari pelepah kurma. Masjid Nabawi dengan ukuran $35 \times 30 \mathrm{~m}$ dindingnya terbuat dari tanah yang dikeringkan, tiangnya dari pohon kurma dan atap dari pelepahnya (Dahlan [et al.]: 1139, 1135, 1129). Namun demikian di zaman kemajuan Umat Islam masjidmasjid tersebut dibangun dengan bagus dan megah. Tidak hanya masjid-masjid tertua itu, tetapi juga berdiri masjidmasjid indah dan megah di pusat-pusat peradaban Islam, seperti masjid Al-Azhar di Mesir, Masjid Ayasovia di Istanbul, Turki, masjid Ibnu Thulun di Tunisia, dan sampai ke Indonesia pun sekarang dapat disaksikan keindahan dan kemegahan masjid yang dirancang dengan arsitektur dan seni yang menakjubkan dan malah telah membaur dengan kebudayaan setempat. 
Pendapat Ulama tentang Pembangunan Masjid

Membangun masjid sebagai pusat ibadah dan kebudayaan Umat Islam memang suatu keharusan. Ditinjau dari sudut hukum Islam (fikih) ulama mazhab Hanbali berpendapat membangun masjid di kota-kota dan di desa-desa hukumnya fardhu kifayah. Membangun masjid secara individual hukumnya sunnah. (Dahlan, [et al.]: 1120). Harapan-harapan yang dijanjikan terhadap orang yang membangun masjid ini sangat menarik. Dalam salah satu Hadis Nabi Muhammad SAW disebutkan: Siapa yang membangun masjid di dunia dengan mengharap kerelaan dari Allah, maka Allah akan membangunkannya sebuah rumah di syorga. (H.R. Al-Bukhari dan Muslim)

Adanya harapan-harapan yang diberikan kepada orang yang membangun masjid juga ada beberapa peringatan yang harus diperhatikan. Secara fisik pembangunan masjid dengan cara yang sudah berlebihan tidak dianjurkan, karena yang lebih penting dari itu adalah membangun orang-orang di sekitar masjid, sehingga mereka bisa meramaikan masjid. Nabi Saw bersabda: Akan datang suatu masa, yaitu orang-orang hanya suka berlomba-lomba menghiyasi masjid masjid, tetapi tidak meramaikan kecuali hanya sedikit (HR Ibn Khuzaimah). Di samping itu Rasul Saw juga bersabda: Aku tidak diperintah untuk meninggikan bangunan masjid. Ibnu Abbas berkata: Nanti suatu ketika kamu akan menghiyasi masjid sebagaimana dilakukan oleh golongan Yahudi dan Nasrani. Umar bin Khattab ketika membangun masjid berkata: Maksud saya adalah ingin menjaga agar orang-orang tidak sampai kehujanan, tapi sekali-kali jangan diberi warna merah dan kuning, sebab akan menimbulkan fitnah belaka. (HR. Ibn Khuzaimah) (Dahlan [et al.]: 1126).

Menurut ulama mazhab Maliki dan Hanbali menghiasi masjid hukumnya makruh, karena dapat mengganggu kekhusyukan orang yang beribadah. Akan tetapi mazhab Hanafi membolehkan mengukir dan melukis masjid dengan bahan yang halal. Menurut mereka yang dimakruhkan hanyalah menghiyasi mihrabnya, karena dapat membuat orang yang shalat menjadi lalai.

Menurut Mazhab Syafi'i, Hanafi dan Hanbali melukis sesuatu di dinding masjid hukumnya makruh. Akan tapai mazhab Maliki dan Hanbali berpendapat bahwa yang dimakruhkan hanyalah melukis sesuatu di dinding masjid sebelah depan, karena dapat mengganggu kekhusyukan orang yang shalat. Tulisan itu dapat menyebabkan orang yang sedang shalat membacanya. Sedangkan melukis di dinding yang lain menurut mereka dibolehkan.

Uraian di atas memberikan informasi bahwa ulama mazhab yang empat sependapat bahwa melukis atau mengukir masjid hukumnya makruh apabila akan mengganggu konsentrasi (khusu') orang yang shalat. Yang mereka perbedakan hanyalah tulisan, lukisan atau ukiran yang tidak akan mengganggu orang yang shalat.

Terlepas dari perbedaan pendapat di atas, menurut hemat penulis ada beberapa hal yang harus dipertimbangkan dalam pembangunan fisik masjid. Pertama harus hati-hati untuk tidak terjebak pada kemubaziran; kedua, harus dipikirkan karena kemegahannya dapat mengundang orang yang berniat jahat mendatanginya; 
dan ketiga, tidak menimbulkan rasa kecemburuan dan perasaan hiba atau iri hati bagi fakir miskin dan orang-orang yang tidak mampu. Memang banyak hadis Nabi Saw yang menganjurkan untuk membangun masjid, di antaranya hadis yang diriwayatkan oleh Bukhari dan Muslim di atas. Akan tetapi apabila pembangunan masjid telah membawa pada kemubaziran hukumnya menjadi haram. Dalam hal kemubaziran ini Allah berfirman:

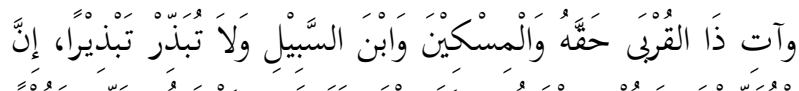

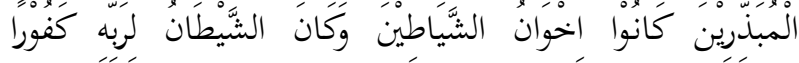
$\{27-26:$ الإسران

Berikanlah kepada karib kerabat haknya masing-masing dan kepada orang miskin dan orang musafir dan janganlah engkau mubazir (pemboros) dengan semubazirmubazirnya. Sesungguhnya orang-orang yang mubazir itu adalah saudara syetan, dan syetan itu amat engkar kepada Tuhannya. (Q.S. Al-Isra'[17]: 26-27)

Kemubaziran itu bisa saja berupa hiyasan yang berlebihan atau mencolok, merenovasi bagian-bagian yang belum selayaknya direnovasi, membongkar masjid yang belum seharusnya dengan bangunan masjid yang baru dan lain-lain sebagainya. Menurut penulis hal-hal yang semacam ini merupakan perbuatan yang terlarang dan sangat tercela sebagaimana diinformasikan oleh ayat di atas, karena betapa banyak kepentingan-kepentingan umat dan dakwah Islam lebih diutamakan dari pada pembangunan fisik masjid yang berlebihan. Dengan kata lain, pembangunan yang bersifat nonfisik tidak boleh terabaikan dengan alasan membangun fisik masjid.
Di samping kemubaziran, pembangunan fisik masjid yang berlebihan dapat mengundang dan menyampaikan niat orang-orang jahat. Fasilitas, peralatan, perlengkapan dan hiyasan yang mahal akan selalu menjadi incaran para pencuri. Dalan kenyataannya betapa banyak fasilitas masjid yang hilang karena dicuri oleh penjahat.

Pembangunan masjid yang megah dan berlebihan dapat menimbulkan kecemburuan sosial di kalangan orangorang fakir, miskin, anak yatim dan orang-orang yang tak mampu lainnya. Karena mungkin saja dibalik tembok keramik yang mengkilat itu terdapat fakir miskin yang tidak makan, anak-anak putus sekolah karena ketiadaan biaya atau anak yatim yang butuh uluran tangan dari kaum muslimin. Hal semacam ini tentu akan menambah luka hati mereka dan membuat mereka tidak peduli ke masjid. Lebih berat lagi apabila perlakuan seperti ini dihubungkan dengan firman Allah berikut:

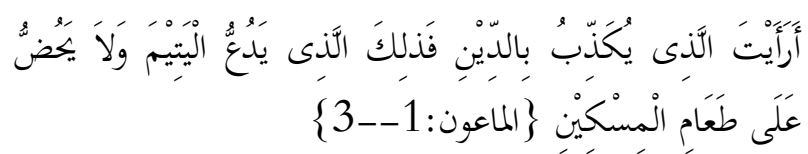

Adakah engkau perhatikan orang yang mendustakan agama? yaitu orang yang mengusir anak yatim dan tidak menyuruh memberi makan orang miskin (Q.S. AlMa'un [107]: 1-3)

Melalui ayat di atas orang muslim dicap oleh Allah Swt. sebagai pendusta agama bilamana mengusir anak yatim dan tidak menganjurkan membari makan orang miskin. Substansi ayat tersebut adalah ancaman terhadap orang-orang yang tidak peduli kepada anak yatim dan fakir miskin. Sedangkan orang yang tidak membangun masjid tidak pernah dicap 
oleh Allah seperti demikian. Jadi, tentu lebih penting mempedulikan masyarakat lingkungan, dalam hal ini anak yatim dan fakir miskin lebih diproduktifkan daripada membangun masjid, apalagi pembangunan fisik masjid yang berlebihan.

Sebenarnya, untuk mengantisipasi kekhawatiran-kekhawatiran di atas, selain dari pembangunan fisik, pembangunan masjid seyogyanya diarahkan pada halhal yang bersifat non fisik. Pembangunan nonfisik tidak kalah penting dibanding pembangunan fisik. Dalam bahasa Alquran pembangunan non fisik ini disebut dengan imarah al-masajid (memakmurkan, menyemarakkan masjid). Sehubungan dengan hal ini Allah berfirman dalam Alquran sebagai berikut:

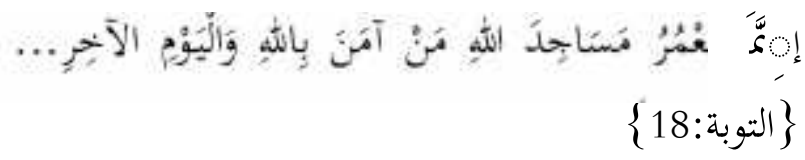

"Hanya yang memakmurkan masjid Allah ialah orang yang beriman dengan Allah dan hari akhirat" (Q.S. At-Taubah [9]: 18)

Al-Maragi dalam menafsirkan kata mengatakan maksudnya adalah menyemarakkan masjid secara umum (al-Maragi, 4:72). Dalam hal ini memberikan pembiayaan terhadap orangorang yang memberikan pendidikan di masjid merupakan salah satu bentuk dari memakmurkan masjid atau membangun masjid secara nonfisik. Begitu juga memberikan pembiayaan terhadap petugaspetugas lainnya yang mengkonsentrasikan dirinya dalam mengurus masjid serta memberikan pembiayaan terhadap aktivitas dakwah Islamiyah dan lain-lain sebagainya.
Untuk pembangunan sektor non fisik masjid sangat luas cakupannya. Hal ini sesuai dengan fungsi masjid itu sendiri. Sidi Gazalba menyebutkan, selain tempat ibadah, di zaman Nabi Saw dan sahabatnya masjid digunakan sebagai tempat menyelesaikan perkara dan pertikaian, tempat menyelesaikan persoalan masyarakat dan negara, tempat menyelesaikan administrasi pemerintahan, tempat penerimaan delegasi bangsa dan negara lain, tempat dewan penasehat kepala negara, tempat perencanaan strategi dan taktik perang, tempat penghulu atau qadhi memimpin upacara pernikahan. Lebih lanjut Gazalba menginformasikan masjid bertugas sebagai hotel bagi kaum musafir yang dalam perjalanan. Pada akhirnya beliau menyimpulkan bahwa masjid merupakan pangkal tolak dari tiap segi kehidupan yang menyangkut kesejahteraan bersama, masjid juga merupakan ujung dari tiap segi kehidupan. (Gazalba: 124,125).

Walaupun yang digambarkan Sidi Gazalba di atas merupakan sosok masjid di zaman Rasulullah dan Sahabatnya, namun substansinya dapat disesuaikan dengan perkembangan situasi dan kondisi sistem pemerintahan di segala zaman, termasuk di zaman sekarang. Pada zaman sekarang lembaga-lembaga yang disebutkan itu sudah banyak yang terpisah dari masjid, seperti lembaga peradilan, dewan penasehat Kepala Negara, markas besar tentara dan lain-lain sebagainya. Namun demikian pemisahan tersebut tidak berarti melepaskan substansi dan nilai-nilai yang dikembangkan di zaman Rasulullah. Sehingga masjid sekarang masih tetap relevan sebagai pangkal tolak dan sasaran berbagai aktifitas kaum muslimin. 


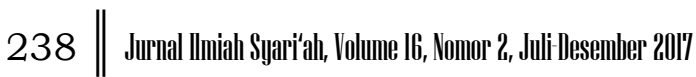

\section{Hasil Penelitian}

\section{Zakat untuk Pembangunan Masjid}

Dalam tradisi pembangunan masjid di Indonesia biasanya dibiayai melalui beberapa sumber pembiayaan. Sumbersumber pembiayaan tersebut seperti: wakaf, infak, sadaqah dan zakat. Wakaf merupakan sumbangan dalam bentuk benda yang dapat dijadikan langsung sebagai bahan pembangunan masjid seperti batu, pasir, atau tanah sebagai tempat pembangunan masjid. Oleh karena itu menurut jumhur ulama harta wakaf tidak boleh dihancurkan dan dialihfungsikan. Dia harus merupakan benda yang tertahan sampai habis.

Infak merupakan pemberian harta kekayaan yang pemamfaatan atau penggunaannya lebih bebas dari pada wakaf. Bilamana infak itu dalam bentuk uang, dia bisa dimanfaatkan untuk pembelian atau pengadaaan bahan sesuai dengan kebutuhan bangunan masjid. Dalam hal ini sadaqah hampir sama dengan infak, yaitu ada kebebasan dalam pemanfaatannya.

Sumber-sumber pembangunan masjid dari wakaf, infak dan sadaqah nampaknya tidak menimbulkan permasalahan dalam hukum Islam, karena di samping ketiganya merupakan amalan sunat, sasarannya tidak dibatasi. Dengan kata lain sasarannya sangat luas, termasuk untuk pembangunan masjid, baik fisik maupun non fisik. Dalam Alquran memang disebutkan beberapa sasaran dari pendistribusian harta wakaf, infak dan sadaqah itu, namun tidak ada pembatasannya, seperti tersebut dalam ayat berikut ini:

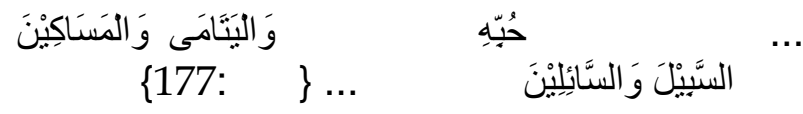

...dan memberikan harta yang dikasihinya kepada karib kerabatnya, anak-anak yatim, orang-orang miskin, orang berjalan (musafir), orang yang meminta-minta dan untuk memerdekakan hamba sahaya... (Q.S. [2]: 177)

Hal di atas berbeda dengan zakat. Zakat ditentukan orang-orang yang berhak menerimanya, sebagaimana disebutkan dalam surat at-Taubah ayat 60 . pertanyaannya adalah: apakah boleh memberikan harta zakat kepada selain yang disebutkan ayat tersebut ? Termasuklah ke dalam hal ini memberikan zakat untuk pembangunan fisik masjid. Padahal dalam kenyataannya ada pembangunan masjid yang berasal dari harta zakat. Permasalahan ini timbul karena di dalam Alquran atau Hadis Nabi Saw tidak ada dinyatakan secara tegas kebolehan atau ketidakbolehan zakat diberikan untuk pembangunan masjid.

\section{Pendapat Ulama tentang Zakat untuk Pembangunan Masjid}

Untuk menjawab permasalahan di atas ada dua versi pendapat ulama tentang zakat untuk pembangunan masjid. Pendapat pertama membolehkan dan pendapat kedua tidak membolehkan.

\section{Pendapat Pertama}

Pendapat yang membolehkan mengambil alasan dengan keumuman penafsiran kata sabilillah (سبيل الله) dalam Q.S. [9]: 60 sebagai salah satu macam yang berhak menerima zakat. Sabilillah secara umum berarti jalan yang ditempuh untuk mencapai keridhaan Allah. Menurut mazhab Ja'fari (Syi'ah Imamiyah) dan Zaidiyah sabilillah adalah sebagala amal perbuatan yang mendekatkan diri kepada 
Allah atau untuk kemaslahatan bersama, seperti ibadah haji, jihad, mendirikan jembatan dan lain-lain. Menurut Rasyid Ridha sabilillah adalah kemaslahatan umum kaum muslimin yang dengannya tegak urusan agama dan negara. Menurut Mahmud Syaltut sabilillah adalah kemaslahatan umum yang bukan milik perorangan, pemilikannya hanya untuk Allah dan pemanfaatannya untuk makhluk. (Qardhawi: 621,623). Ke dalam pengertian yang dikemukakan ini tentu termasuk pembangunan fisik masjid.

Kebolehan zakat untuk keperluan pembangunan masjid ini menurut Yusuf Qardhawi juga dapat melalui ashnaf yang lain, yaitu orang yang berutang (gharim) untuk pembangunan masjid. Maka zakat boleh diberikan kepadanya untuk menutupi utangnya. Yusuf Qardhawi menyebutkan, orang yang berutang ada dua bentuk. Pertama berutang untuk kemaslahatan dirinya dan yang kedua berutang untuk kemashlahatan orang lain. Orang yang berutang untuk keperluan diri sendiri seperti untuk nafkah, membeli pakaian, melaksanakan perkawinan, mengobati sakit, mendirikan rumah, membeli perabot rumah, mengawinkan anak, mengganti barang orang lain yang dirusak karena kesalahan, lupa dan sebagainya. Abu Ja'far dan Qatadah memberikan kriteria bahwa orang yang berutang itu tidak berlebih dalam memanuhi kebutuhan pokoknya. (Qardhawi: 595).

Sedangkan yang termasuk berutang untuk kemaslahatan orang lain adalah orang-orang yang mempunyai nilai kemanusiaan, kemuliaan yang tinggi, citacita yang tinggi seperti untuk mendamaikan orang yang bersengketa.
Yusuf Qardhawi memasukkan ke dalam jenis ini orang-orang yang bergerak dalam kegiatan sosial yang bermanfaat seperti yayasan anak yatim, rumah sakit orangorang fakir, masjid untuk mendirikan shalat, sekolah-sekolah untuk tempat belajar kaum muslimin atau perbuatan lain yang bertujuan untuk melayani masyarakat. Alasanya adalah bahwa dalil yang ada tidak mengkhususkan gharimin (orang yang berutang) saja, begitu juga pada yang lain. Oleh karena itu, seandainya orang tersebut tidak termasuk kepada gharimin, tentu wajib menempatkannya sebagai garimin dengan jalan qiyas. (Qardhawi: 604).

\section{Pendapat Kedua}

Jumhur fukaha, sebagaimana dikemukakan oleh Wahbah Zuhaili, berpendapat tidak boleh memberikan zakat kepada selain yang disebutkan Allah dalam Alquran seperti membangun masjid, jembatan, waduk, menggali sungai, memperbaiki jalan, mengapani mayat dan lain-lain sebagainya yang kesemuanya tidak menunjukkan kepemilikan. Alasannya adalah karena yang berhak menerima zakat itu telah dibatasi oleh Allah dengan kata (hanya). Oleh karena itu tidak boleh dibagikan kepada yang lain. (Zuhaili, 2: 875).

Adapun makna sabilillah menurut jumhur tidak mencakup kepada kemaslahatan umum. Sabilillah maksudnya adalah jihad atau berperang di jalan Allah. Dan orang yang mendapat bagian zakat adalah tentara yang tidak digaji oleh pemerintah, yaitu tentara sukarelawan. (Sayyid Sabiq, 1: 463).

Memberikan zakat untuk pembangunan masjid berarti memakaikan makna yang 
sangat umum kepada sabilillah karena ada sabilillah yang tidak berhak menerima zakat, seperti orang melaksanakan haji.

Selanjutnya apabila sabilillah ditafsirkan dengan sangat umum tentu tidak ada lagi artinya menyebut ashnaf yang tujuh lainnya, karena semuanya termasuk sabilillah. Disebabkan sabilitlah mempunyai pengertian tersendiri, maka Allah membedakannya dari ashnaf yang lain.

Dengan memperhatikan perbedaan pendapat fukaha di atas dalam memberikan zakat untuk pembangunan masjid, kemudian dihubungkan dengan pembangunan masjid yang biasa dilakukan saat ini ada beberapa rumusan atau kesimpulan yang perlu diperhatikan.

Pertama; apabila dipegangi pendapat pertama, yang membolehkan dengan alasan sabilillah mengandung pengertian yang umum, maka pendistribusian zakat bisa terkonsentrasi untuk pembangunan masjid, padahal masih banyak lagi kepentingan lain yang mendesak dengan pembiayaan yang besar selain pembangunan fisik masjid. Masyarakat biasanya lebih aman dan puas memberi ke masjid daripada memberi kepada fakir miskin dan ashnaf lainnya. Lebih tidak tepat sasaran lagi apabila zakat itu diberikan ke masjid yang sudah selesai dibangun, tinggal lagi untuk penyempurnaanpenyempurnaan fisik yang tidak begitu penting.

Mencukupkan sumber pembiayaan pembangunan fisik masjid dari wakaf, infak, dan sedekah merupakan sikap kehatian-hatian (ihtiyath) untuk tidak terjebak ke dalam keraguan atas keabsahan zakat ke masjid. Sehingga zakat itu betulbetul dapat diberikan kepada orang yang berhak menerimanya dan mencapai sasaran untuk kesejahteraan masyarakat.
Apabila kebolehan berzakat untuk pembangunan masjid dengan mengkategorikan pengurusnya sebagai gharimin, dalam kenyataannya zakat yang diberikan itu bukan untuk pengurus, tetapi tetap untuk pembangunan. Sedangkan pengurus hanya bertindak sebagai penyalur zakat tersebut. Oleh karena itu sulit menudukkan pengurus sebagai orang yang berutang, sebagaimana yang disebut dengan istilah gharimin. Apalagi penafsiran gharimin itu adalah individu yang berutang (utang individu), baik untuk kepentingan dirinya atau kepentingan orang lain, bukan kelompok yang berutang (utang kolektif). Karena, utang kolektif seperti untuk pembangunan masjid itu tidak jelas jumlahnya.

Kedua; sebaliknya apabila kita berpegang secara ketat kepada pendapat kedua yang tidak membolehkan zakat untuk pembangunan fisik masjid, menurut hemat penulis juga kurang tepat. Karena, bilamana sama sekali tidak dibolehkan, ada kemungkinan akan berbenturan dengan kebutuhan yang sangat mendesak, seperti untuk pembangunan masjid di sebuah perkampungan yang belum memiliki masjid sama sekali. Padahal dana zakat ada yang bisa dialokasikan untuk mempercepat pembangunan tersebut. Tentu hal ini merupakan sesuatu yang lebih penting, dengan alasan pengecualian karena al-haajah (kebutuhan mendesak).

\section{PENUTUP}

Setelah melakukan pembahasan dalam tulisan ini penulis berkesimpulan bahwa zakat untuk pembangunan masjid pada dasarnya tidak dibolehkan, karena tidak termasuk ashnaf penerima zakat. 
Namun demikian bila situasi dan kondisi menghendaki dapat dilihat dari sudut kebutuhan mendesak (al-Haajah). Dengan alasan pengecualian ini zakat boleh untuk pembangunan masjid. Tetapi kalau tidak ada kondisi yang sangat mendesak, maka zakat tidak boleh diberikan untuk pembangunan masjid.

\section{DAFTAR KEPUSTAKAAN}

Ahmad bin Musthafa al-Maragi. 1365/1946. Tafsir al-Maraghiy, Mishr: Mathbaah Musthafa al-Babi alHalabiy.

Dahlan, Abdul Aziz [et al.]. 1996. Ensiklopedi Hukum Islam. Jakarta: Ichtiar Baru van Hoeve.

Departemen Agama R.I, Alquran dan Terjemahannya
Gazalba, Sidi. 1983. Masjid Pusat Ibadat dan Kebidayaan Islam. Jakarta: Pustaka Antara.

https://kbbi.kemdikbud.go.id/

Muhammad bin Ismail abu Abdillah alBukhari. 1422. Shahih al-Bukhariy, Dar Thuq an-Najah, Cet. 1.

Muhammad, Abu Bakr bin Khuzaimah. 1424/2003. Shahih Ibn Khuzaimah, AlMaktab al-Islamiy, Cet.3.

Muslim bin Hajjaj Abu al-Hasan, alQusyairi an-Naisaburiy. t.th. Shahih Muslim. Beirut: Dar Ihya At-Turats al-'Arabiy.

Sabiq, Sayyid. 1397/1977. Fiqh as-Sunnah. Beirut: Dar al-Kitab al-Arabiy.

Wahbah bin Musthafa az-Zuhaili. t.th. alFigh al-Islamiy wa Adillatuh. Damaskus: Dar al-Fikr. 